\title{
Perbedaan Kepuasaan Pasien Terhadap Makanan Dengan Sistem Penyelenggaraan Outsourcing Dan Swakelola Di RS Islam Jemursari Surabaya
}

\section{Difference Patient Satisfaction of Food by Outsourcing and Self Operated Foodservice System in RS Islam Jemursari Surabaya}

\author{
Susila Rusdiana Dewi*1 ${ }^{1}$, Merryana Adriani ${ }^{1}$
}

\begin{abstract}
ABSTRAK
Latar belakang : Kepuasan makan pasien merupakan salah satu output yang diharapkan oleh suatu penyelenggara makanan. Pemilihan dalam sistem penyelenggaraan makanan khususnya di rumah sakit akan mempengaruhi kualitas dan pelayanan makanan yang nantinya juga akan berpengaruh pada daya terima dan asupan makan pasien.

Tujuan : Penelitian ini bertujuan untuk melihat perbedaan kepuasan makanan pasien pada penyelenggaraan makanan secara outsourcing dan swakelola berdasarkan kualitas makanan dan kualitas pelayanan makanan yang telah dilaksanakan di RS Islam Jemursari Surabaya.

Metode : Penelitian ini merupakan penelitian deskriptif dengan desain penelitian cross sectional. Penelitian ini menggunakan dua jenis data yakni data sekunder (untuk mengetahui kepuasan pasien terhadap makanan pada saat sistem outsourcing) dan data primer (untuk mengetahui kepuasan pasien terhadap makanan pada sistem swakelola). Ukuran kualitas makanan dan kualitas pelayanan makanan yang digunakan pada saat survey outsourcing sama dengan yang digunakan saat swakelola. Populasi pada penelitian ini adalah semua pasien kelas 2 dan 3 yang ada di Ruang Azzahra 1, Azzahra 2, dan Mawar dengan sampel penelitian masing-masing sistem penyelenggaraan sebanyak 43 pasien. Uji analisis yang digunakan adalah uji Mann Whitney.

Hasil : Hasil analisis statistik dari penelitian ini menunjukkan bahwa tidak ada perbedaan bermakna pada kualitas makanan $(p>0,100)$ dan kepuasan makanna total $(p>0,100)$, namun ada perbedaan bermakna pada kualitas pelayanan makanan $(p<0,100)$.

Kesimpulan : Kepuasan makan pasien pada penyelenggaraan makanan sistem outsourcing tidak berbeda dengan kepuasan makan pada penyelenggaraan sistem swakelola.
\end{abstract}

Kata Kunci: penyelengaraan makanan,kepuasan makan, ousourching, swakelola 


\section{ABSTRACT}

Background : Patient satisfaction is one of expected outputs of food provision. Food service system selection, especially in the hospital, will influence food and foodservice quality, which can influence patient's acceptance and food intake.

Objectives: The Purpose of this study was to analyze the difference between food satisfaction on foodservice as outsouching and self operated based on food quality and foodservice quality which had been held in RS Islam Jemursari Surabaya.

Method : The study was a description research with cross sectional design. The study used two kinds of data, which were secondary data (to know the patient satisfaction of food by outsourcing system) and primaly data (to know the patient satisfaction of food by self operated system). Measures of food and foodservice quality by outsourcing system was same by self operated system. Population of the study were all of patient which in 2 and 3 class at Azzahra 1'room, Azzahra 2'room, and Mawar'room so that sampels of the study in each food service system were 43 patients. Analysis test used was Mann Whitney test.

Result : The result of the statistical analysis showed that there was no significant difference in food quality $(p<0.100)$ and total food satisfaction $(p>0.100)$, but there was significant difference in foodservice quality $(p<0.100)$.

Conclusion : Patient satisfaction of food by outsourcing system was no difference from the patient satisfaction of food by self operated system.

Keywords: foodservice, food satisfaction, outsourcing, self operated

\footnotetext{
*Koresponden:

susirdewi29@gmail.com

${ }^{1}$ Departemen Gizi Kesehatan, Fakultas

Kesehatan Masyarakat-Universitas Airlangga
} 


\section{PENDAHULUAN}

Rumah sakit merupakan salah satu fasilitas pelayanan kesehatan yang memiliki peranan penting dalam meningkatkan derajat kesehatan masyarakat dalam penyelenggaraannya minimal pelayanan yang harus ada adalah pelayanan gizi. Pelayanan gizi yang dimaksud salah satunya berkaitan dengan penyelenggaraan makanan untuk pasien rawat inap di rumah sakit ${ }^{1,2}$. Penyelenggaraan makanan di rumah sakit dianggap penting karena merupakan faktor penunjang dalam peningkatan kondisi status pasien. Rumah sakit dituntut dapat menyediakan makanan yang berkualitas sesuai dengan kebutuhan gizi, biaya, aman, dan dapat diterima oleh pasien guna mencapai status gizi yang optimal ${ }^{3}$.

Pelayanan gizi di rumah sakit erat kaitannya dengan asupan makan pasien. Asupan makanan dapat mempengaruhi status gizi pasien tersebut. Pemberian makanan yang tidak adekuat dapat mengakibatkan malnutrisi yang nantinya berujung pada morbiditas dan mortalitas. Tingkat kecukupan energi yang kurang akan menyebabkan pasien beresiko 2,1 kali lebih besar mengalami malnutrisi daripada pasien yang tingkat kecukupan energinya baik ${ }^{4}$. Pasien yang memiliki resiko malnutrisi akan memerlukan waktu rawat inap hampir dua kali lipat daripada pasien tanpa resiko malnutrisi ${ }^{4}$.

Asupan makan pasien salah satunya dapat dipengaruhi oleh kepuasan terhadap pelayanan makan di rumah sakit ${ }^{4}$. Kepuasan pasien yang tinggi terhadap pelayanan makanan akan meningkatkan asupan makan pasien sehingga sisa makanan pasien sedikit ${ }^{4}$. Kepuasan pasien terhadap makanan secara signifikan bergantung pada kualitas makanan, variasi makanan, sikap penyaji makanan, pelayanan makanan, ketepatan waktu pemberian makan, serta keandalan dalam pelayanan makanan. Selain itu, penelitian lain yang menyebutkan adanya korelasi yang signifikan antara kepuasan makan dengan besar porsi, aroma dan rasa makanan yang diberikan ${ }^{5}$.

Kualitas dan pelayanan makanan merupakan salah satu faktor yang paling penting dari penyelengaraan makanan rumah sakit. Penyelenggaraan makanan pasien di rumah sakit dapat menerapkan beberapa bentuk sistem penyelenggaraan makanan diantaranya dengan sistem swakelola, sistem outsourcing, maupun kombinasi antara swakelola dan outsourcing ${ }^{3}$. Pada sistem swakelola, penyelenggaraan makanan dikelola langsung oleh pihak instalasi gizi rumah sakit. Berbeda dengan sistem outsourcing dimana penyelengaraannya memanfaatkan jasa boga atau catering. Sistem kombinasi merupakan perpaduan dari sistem swakelola dan outsourcing dimana pihak rumah sakit hanya memanfaatkan jassa boga untuk penyediaan makanan bagi pasien VIP atau makanan karyawan dan selebihnya dikelola sendiri oleh pihak rumah sakit ${ }^{3}$. Berbagai sistem penyelenggaraan makanan tersebut akan berpengaruh pada mutu makanan yang merupakan output dari proses penyelenggaraan makanan ${ }^{6}$. Mutu makanan adalah salah satu faktor utama yang dapat mempengaruhi kepuasan pasien terhadap pelayanan makanan ${ }^{6}$

RS Islam Jemursari Surabaya merupakan salah satu rumah sakit islam swasta di Surabaya yang sejak awal berdiri, instalasi gizinya meggunakan sistem outsourcing dalam penyelenggaraan makanannya. Kemudian sejak awal Desember 2016, instalasi gizi RS Islam Jemursari Surabaya mengubah sistem penyelenggaraan makanannya dari outsourcing menjadi sistem swakelola ${ }^{6}$. Peralihan sistem penyelenggaraan makanan tersebut tentunya dapat mempengaruhi tiga komponen utama manajemen yakni input, process, dan output dari penyelenggaraan makanan dimana nantinya akan berdampak kepuasan makan pasien $^{6,8}$. Penelitian ini bertujuan untuk menganalisis perbedaan tingkat kepuasan makan pasien pada sistem penyelenggaraan outsourcing dan swakelola di RSI Jemursari Surabaya yang nantinya dapat digunakan sebagai bahan pertimbangan keefektifan dan evaluasi dari kedua sistem penyelenggraan tersebut. 


\section{METODE}

Penelitian ini merupakan penelitian cross-sectional. Metode penelitian termasuk penelitian studi komparatif dengan dua sampel bebas yakni membandingkan tingkat kepuasan pasien terhadap pelayanan makanan pada sistem outsourcing dan sistem swakelola di RS Islam Jemursari Surabaya. Populasi dalam penelitian ini adalah pasien rawat inap kelas 2 dan kelas 3 di RS Islam Jemursari Surabaya yang berjumlah 76 pasien. Pemilihan kelas dalam penelitian ini terkait dengan kebijakan instansi runah sakit. Besar sampel yang diambil pada penyelenggaraan makanan sistem outsourcing dan swakelola masing-masing sebesar 43 responden. Penelitian ini memiliki dua jenis data yakni data kepuasan makan pasien sistem outsourcing berupa data sekunder dan data kepuasan makan pasien sistem swakelola berupa data primer. Pemilihan sampel dilakukan dengan menentukan sampel sesuai kriteria inklusi sampel yaitu pasien kelas $2 \& 3$ yang bersedia menjadi responden yakni pasien yang di rawat inap di Ruang Azzahra 1, Ruang Azzahra 2, Ruang Mawar $\geq 2$ hari dan telah mendapatkan pelayanan makanan dari rumah sakit baik makan pagi, siang, maupun sore, pasien dalam keadaan sadar dan mendapat diet secara oral baik makanan biasa maupun lunak tanpa memperhitungkan jenis diet pasien, pasien berusia antara 18 - 50 tahun. Selanjutnya sampel tiap ruangan diambil secara proporsional berdasarkan jumlah pasien saat dilakukan survey. Cara pengambilan sampel dilakukan dengan cara cluster random sampling dan diambil secara acak. Ukuran kualitas makanan dan kualitas pelayanan makanan yang digunakan pada saat survey outsourcing sama dengan yang digunakan saat survey swakelola Variabel indipenden dalam penelitian ini yaitu kualitas makanan dan kualitas pelayanan makanan. Ukuran kualitas makanan yang diukur meliputi warna makanan, besar porsi, dan variasi menu, kematangan makanan, rasa bumbu makanan, dan aroma makanan ${ }^{6}$. Sedangkan ukuran kualitas pelayanan makanan yang diukur adalah ketepatan waktu pemberian makan, kebersihan alat hidang, dan pelayanan petugas pengantar makanan ${ }^{6}$. Selanjutnya untuk variabel dependen dalam penelitian ini yaitu kepuasan makan pasien. Tiap variabel tersebut dinilai oleh responden berdasarkan skoring kepuasan dengan menggunakan 4 skala yakni sangat tidak puas, tidak puas, puas, dan sangat puas. Selanjutnya data tersebut diolah dan dianalisis menggunakan uji Mann Whitney.

\section{HASIL DAN PEMBAHASAN}

\section{Karakteritik responden}

Karakteristik responden dalam penelitian ini meliputi jenis kelamin, umur, dan jenis makanan responden yang disajikan pada tabel 1. Tabel 1 menunjukkan bahwa kelompok umur responden terbanyak pada penyelenggaraan makanan sistem outsourcing adalah kelompok umur antara 39 - 59 tahun yakni sebesar $48,8 \%$. Sedangkan pada penyelenggaraan makanan sistem swakelola kelompok umur responden terbanyak antara umur 18 - 38 tahun yakni sebesar 51,2 \%. Kemudian untuk jenis kelamin responden terbanyak adalah perempuan dengan prosentase yang sama pada saat sistem outsourcing dan swakelola yakni masingmasing sebesar $72,1 \%$. Jenis makanan diet terbanyak yang dikonsumsi responden baik pada sistem penyelenggaraan makanan secara outsourcing maupun swakelola adalah diet TKTP (Tinggi Kalori Tinggi Protein). Berdasarkan penelitian Fallon et al, jenis diet merupakan salah satu dari faktor individu yang dapat mempengaruhi kepuasan makan pasien ${ }^{9}$.

\section{Kepuasan Makan Berdasarkan Kualitas Makanan (Food Quality)}

Hasil pengamatan kepuasan makan pada penyelenggaraan makanan sistem outsourcing dapat dilihat pada tabel 2 yang menunjukkan bahwa lebih dari $90 \%$ responden merasa puas terhadap kualitas makanan (food quality) dan kualitas pelayanan makanan (foodservice quality). Pada penyelenggaraan makanan sistem swakeloa, penilaian kepuasan makanan oleh reponden lebih bervariasi dimana lebih dari $60 \%$ responden menyatakan puas. 
Salah satu output dari penyelenggaraan makanan adalah kepuasan makan dimana hal tersebut merupakan tolak ukur keberhasilan suatu proses dari penyelenggaraan makanan mulai dari persiapan bahan hingga pendistribusian ke konsumen ${ }^{6}$. Kualitas makanan turut menentukan kepuasan makan pasien ${ }^{6}$.

Tabel 1. Distribusi Umur, Jenis Kelamin, Dan Jenis Diet Responden RS Islam Jemursari Surabaya Tahun 2017

\begin{tabular}{|c|c|c|c|c|}
\hline \multirow{2}{*}{ Karakteristik pasien } & \multicolumn{2}{|c|}{ Outsourcing } & \multicolumn{2}{|c|}{ Swakelola } \\
\hline & $\mathbf{n}$ & $\%$ & $\mathbf{N}$ & $\%$ \\
\hline \multicolumn{5}{|l|}{ Kelompok umur (tahun) } \\
\hline \multirow{3}{*}{$\begin{array}{l}18-38 \\
39-59 \\
\geq 60\end{array}$} & 16 & 14,0 & 22 & 51,2 \\
\hline & 21 & 48,8 & 14 & 32,6 \\
\hline & 6 & 37,2 & 7 & 16,3 \\
\hline Total & 43 & 100 & 43 & 100 \\
\hline \multicolumn{5}{|l|}{ Jenis kelamin } \\
\hline \multirow{2}{*}{$\begin{array}{l}\text { Perempuan } \\
\text { laki-laki }\end{array}$} & 31 & 72,1 & 31 & 72,1 \\
\hline & 12 & 27,9 & 12 & 27,9 \\
\hline Total & 43 & 100 & 43 & 100 \\
\hline \multicolumn{5}{|l|}{ Jenis makanan } \\
\hline \multirow{3}{*}{$\begin{array}{l}\text { diet TKTP } \\
\text { diet cacah (RS) } \\
\text { diet } K V / R L / R G / D M\end{array}$} & 20 & 46,5 & 20 & 46,5 \\
\hline & 5 & 11,6 & 5 & 11,6 \\
\hline & 18 & 41,9 & 18 & 41,9 \\
\hline Total & 43 & 100 & 43 & 100 \\
\hline
\end{tabular}

Tabel 2. Distribusi Hasil Survey Kepuasan Makan Pasien Berdasarkan Kualitas Makanan pada Penyelenggaraan Makanan Sistem Outsourcing dan Swakelola

\begin{tabular}{|c|c|c|c|c|c|c|c|c|c|c|c|c|c|c|c|c|}
\hline \multirow{3}{*}{ Indikator penilaian } & \multicolumn{8}{|c|}{ Outsourcing } & \multicolumn{8}{|c|}{ Swakelola } \\
\hline & \multicolumn{2}{|c|}{1} & \multicolumn{2}{|c|}{2} & \multicolumn{2}{|r|}{3} & \multicolumn{2}{|c|}{4} & \multicolumn{2}{|c|}{1} & \multicolumn{2}{|r|}{2} & \multicolumn{2}{|c|}{3} & \multicolumn{2}{|c|}{4} \\
\hline & $\mathbf{n}$ & $\%$ & $n$ & $\%$ & $\mathrm{n}$ & $\%$ & $\mathbf{n}$ & $\%$ & $n$ & $\%$ & $\mathrm{n}$ & $\%$ & $n$ & $\%$ & $\mathrm{n}$ & $\%$ \\
\hline Warna makanan & 0 & 0 & 0 & 0 & 41 & 95,3 & 2 & 4,7 & 0 & 0 & 0 & 0 & 29 & 67,4 & 14 & 32,6 \\
\hline Besar porsi & 0 & 0 & 0 & 0 & 41 & 95,3 & 2 & 4,7 & 0 & 0 & 1 & 2,3 & 31 & 72,1 & 11 & 25,6 \\
\hline Variasi menu & 0 & 0 & 0 & 0 & 41 & 95,3 & 2 & 4,7 & 0 & 0 & 0 & 0 & 29 & 67,4 & 14 & 32,6 \\
\hline $\begin{array}{l}\text { Kematangan } \\
\text { makanan }\end{array}$ & 0 & 0 & 0 & 0 & 41 & 95,3 & 2 & 4,7 & 0 & 0 & 0 & 0 & 30 & 69,8 & 13 & 30,2 \\
\hline Rasa bumbu & 0 & 0 & 0 & 0 & 42 & 97,7 & 1 & 2,3 & 1 & 2,3 & 5 & 11,6 & 30 & 69,8 & 7 & 16,3 \\
\hline
\end{tabular}




\begin{tabular}{|c|c|c|c|c|c|c|c|c|c|c|c|c|c|c|c|c|}
\hline \multirow{3}{*}{ Indikator penilaian } & \multicolumn{8}{|c|}{ Outsourcing } & \multicolumn{8}{|c|}{ Swakelola } \\
\hline & \multicolumn{2}{|c|}{1} & 2 & \multicolumn{3}{|c|}{3} & \multicolumn{2}{|c|}{4} & \multicolumn{2}{|c|}{1} & \multicolumn{2}{|r|}{2} & \multicolumn{2}{|c|}{3} & \multicolumn{2}{|c|}{4} \\
\hline & $\mathbf{n}$ & $\%$ & $\%$ & $n$ & 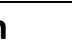 & $\%$ & $\mathbf{n}$ & $\%$ & $\mathbf{n}$ & $\%$ & $\mathrm{n}$ & $\%$ & $\mathbf{n}$ & $\%$ & $\mathbf{n}$ & $\%$ \\
\hline Aroma makanan & 0 & 0 & 0 & 4 & 2 & 97,7 & 1 & 2,3 & 0 & 0 & 5 & 11,6 & 32 & 74,4 & 6 & 11,6 \\
\hline \multicolumn{17}{|c|}{ Keterangan : 1 : sangat tidak puas; 2 : tidak puas; $3:$ puas; 4 : sangat puas } \\
\hline \multicolumn{17}{|c|}{$\begin{array}{l}\text { Tabel 3. Distribusi Hasil Survey Kepuasan Makan Pasien Berdasarkan Kualitas Pelayanan Makanan } \\
\text { pada Penyelenggaraan Makanan Sistem Outsourcing dan Swakelola }\end{array}$} \\
\hline \multirow{3}{*}{ Indikator penilaian } & \multicolumn{8}{|c|}{ Outsourcing } & \multicolumn{8}{|c|}{ Swakelola } \\
\hline & \multicolumn{2}{|r|}{1} & \multicolumn{2}{|c|}{2} & \multicolumn{2}{|r|}{3} & \multicolumn{2}{|r|}{4} & \multicolumn{2}{|r|}{1} & \multicolumn{2}{|r|}{2} & \multicolumn{2}{|r|}{3} & \multicolumn{2}{|c|}{4} \\
\hline & $\mathbf{n}$ & $\%$ & $n$ & $\%$ & $n$ & $\%$ & $n$ & $\%$ & $n$ & $\%$ & $n$ & $\%$ & $n$ & $\%$ & $n$ & $\%$ \\
\hline $\begin{array}{l}\text { Ketepatan waktu } \\
\text { pemberian makan }\end{array}$ & 0 & 0 & 0 & 0 & 43 & 100 & 0 & 0 & 1 & 2,3 & 2 & 4,7 & 26 & 60,5 & 14 & 32,6 \\
\hline $\begin{array}{l}\text { Kebersihan alat } \\
\text { hidang }\end{array}$ & 0 & 0 & 0 & 0 & 43 & 100 & 0 & 0 & 1 & 2,3 & 0 & 0 & 26 & 60,5 & 16 & 37,2 \\
\hline Pelayanan petugas & 1 & 2,3 & 0 & 0 & 42 & 97,7 & 0 & 0 & 1 & 2,3 & 0 & 0 & 42 & 97,7 & 0 & 0 \\
\hline
\end{tabular}

Keterangan : 1 : sangat tidak puas; 2 : tidak puas; 3 : puas; 4 : sangat puas

Tabel 4. Perbedaan Hasil Survey Kepuasan Makan Pasien Antara Sistem Outsourcing dan Swakelola di RS Islam Jemursari Surabaya tahun 2017

\begin{tabular}{|c|c|c|c|}
\hline \multirow{2}{*}{ Indikator penilaian } & \multicolumn{2}{|c|}{ Nilai rata-rata } & \multirow{2}{*}{ P value } \\
\hline & Outsourcing & Swakelola & \\
\hline Kualitas makanan (food quality) & 39,55 & 47,45 & 0,120 \\
\hline Kualitas pelayanan makanan (food service quality) & 35,22 & 51,78 & 0,000 \\
\hline Kepuasan makanan total & 39,55 & 47,45 & 0,123 \\
\hline
\end{tabular}

Kualitas makanan dipengaruhi salah satunya adalah penampilan makanan yang meliputi warna makanan, besar porsi, dan variasi menu $^{10}$.

Berdasarkan hasil skoring penelitian, prosentase responden yang menyatakan puas terhadap warna makanan pada penyelenggaraan makanan sistem outsourcing sebesar $95,3 \%$ responden.

Hal tersebut menandakan bahwa warna makanan yang disajikan pada saat penyelenggaraan makanan dengan sistem tersebut sudah sesuai sehingga menimbulkan kepuasan bagi pasien. Hal yang sama juga terjadi pada penilaian warna makanan pada penyelenggaraan makanan sistem swakelola dimana sebagaian besar responden tidak memiliki keluhan yang terlihat dari $67,4 \%$ responden merasa puas dan sisanya merasa sangat puas. Warna makanan yang disajikan memiliki pengaruh yang signifikan terhadap kepuasan makan pasien ${ }^{12}$. Kombinasi warna makanan yang menarik akan berpengaruh terhadap penampilan makanan sehinnga berpotensi mampu merangsang saraf melalui indera penglihatan yang nantinya akan membangkitkan selera makan ${ }^{12}$. 
Penilaian kepuasan pada indikator porsi penyelenggaraan sistem outsourcing di RS Islam Jemursari sebagaian besar responden menyatakan puas dan sisanya menyatakan sangat puas. Lain halnya dengan penilaian kepuasan besar porsi pada penyelenggaraan makanan sistem swakelola dimana masih ada responden yang menyatakan tidak puas yakni sebesar 2,3 \% walaupun sisanya mayoritas menyatakan puas dan sangat puas. Hal tersebut dibuktikan dengan adanya kritik dari responden mengenai porsi makanan yang dirasa terlalu sedikit. Besar porsi pada penyelenggaraan makanan sistem outsourcing dan swakelola secara keseluruhan tidak memiliki perbedaan tampilan. Besar porsi dapat mempengaruhi penampilan yang nantinya akan berpengaruh pada persepsi pasien sehingga apabila porsi terlalu besar maka akan mempengaruhi daya terima pasien itu sendiri ${ }^{12}$. Munculnya ketidakpuasan terhadap besar porsi dikarenakan adanya ketidakseimbangan antara persepsi dengan harapan terhadap besar porsi yang disajikan 13. Adanya perbedaan pola makan antara pasien di luar rumah sakit dan saat di rumah sakit menjadi salah satu penyebab ketimpangan persepsi mengenai besar porsi ${ }^{12}$. Indikator variasi menu pada penyelenggaraan makanan sistem outsourcing dan swakelola diketahui seluruh responden menyatakan puas. Hal tersebut menandakan bahwa variasi menu yang disajikan pada penyelenggaraan makanan sistem swakelola sudah baik berdasarkan hasil survey kepuasan. Dalam penyelenggaraan makanan baik pada sistem outsourcing dan swakelola menerapkan siklus menu 10 hari dengan tambahan menu ke-11 untuk tanggal 31 . Berdasarkan penelitian yang dilakukan Wulansari dkk (2013) dari hasil tingkat kepentingan dimana tingkat kepentingan yang dimaksud merupakan rata-rata dari skor kepentingan responden, variasi menu makanan yang ditawarkan memiliki nilai tingkat kepentingan dari konsumen sebesar 408 yang artinya variasi menu merupakan aspek penting dalam kepuasan konsumen, dalam hal ini adalah pasien ${ }^{14}$.

Pada indikator kematangan, kepuasan pasien sudah cukup baik baik pada penyelenggaraan makanan sistem outsourcing maupun swakelola. Umumnya tingkat kematangan digunakan untuk mendeskripsikan lauk pauk seperti telur atau daging. Tingkat kematangan juga dapat diaplikasikan untuk menggambarkan kematangan nasi, lauk nabati, buah, dan sayur $^{15}$. Apabila tingkat kematangan suatu makanan tidak sesuai maka akan mempengaruhi rasa makanan itu sendiri.

Indikator rasa bumbu makanan pada penyelenggaraan makanan sistem outsourcing dinilai oleh $97,7 \%$ responden dengan kategori puas. Sedangkan pada sistem swakelola, masih didapatkan 2,3 \% responden menyatakan sangat tidak puas, dan $11,6 \%$ menyatakan tidak puas. Standar bumbu yang digunakan pada penyelenggaraan makanan secara outsourcing dengan swakelola memiliki perbedaan. Hal tersebut dikarenakan penyusunan standar bumbu dilakukan oleh manajemen yang berbeda dimana pada saat sistem outsourcing, standar bumbu disusun oleh pihak catering, sedangkan pada sistem swakelola, standar bumbu disusun oleh head cook dari instalasi gizi RS Islam Jemursari. Selama penelitian ini, beberapa pasien yang disurvey pada penyelenggaraan makanan sistem swakelola yang mendapatkan jenis menu diet TKTP (Tinggi Kalori Tinggi Protein) mengeluhkan rasa sayur yang hambar seperti rasa makanan berdiet seperti menu diet rendah garam.

Umumnya rasa makanan disesuaikan dengan jenis diet pasien ${ }^{15}$. Apabila menu diet rendah garam, maka makanan yang disajikan akan terasa hambar. Lain halnya dengan makanan TKTP atau Tinggi Kalori Tinggi Protein, dimana bumbu lauk hewani, nabati, dan sayurnya terasa tidak hambar. Selain itu ketidakpuasan pasien terhadap rasa makanan yang disajikan oleh pihak rumah sakit juga dapat disebabkan karena kondisi responden dalam hal ini pasien sedang mengalami perubahan sehingga menimbulkan gangguan panca indera ${ }^{16}$. Hal tersebut sesuai dengan pernyataan Jessri et al tahun 2011 yang menyatakan bahwa perbedaan jenis penyakit yang dialami pasien juga dapat mempengaruhi perilaku terhadap makanan seperti pengecapan rasa makanan sehinga akan 
berpengaruh pada penilaian terhadap kepuasan makanan ${ }^{17}$. Rasa bumbu makanan turut menentukan kepuasan makan pasien. Rasa bumbu makanan berpeluang 19,42 kali terhadap kepuasan makan pasien ${ }^{11}$.

Pada indikator aroma, penilaian kepuasan makan terhadap aroma makanan pada penyelenggaraan makanan sistem outsourcing lebih baik daripada sistem swakelola. Aroma yang diteliti dalam penelitian ini adalah aroma lauk hewani, lauk nabati, dan sayur. Aroma makanan terjadi akibat terbentuknya senyawa yang mudah menguap ${ }^{14}$. Hal tersebut menyebabkan timbul rangsangan terhadap indera penciuman sehingga dapat memberikan daya tarik kuat untuk membangkitkan selera makan ${ }^{10}$.

\section{Kepuasan Makan Berdasarkan Kualitas Pelayanan Makanan (Food Service Quality)}

Penilaian kepuasan pelayanan makanan pada sistem outsourcing memiliki prosentase kepuasan yang lebih tinggi daripada penyelenggaraan makanan sistem swakelola. Hal tersebut terlihat dari penilaian ketepatan waktu dan kebersihan alat hidang, seluruh responden menyatakan puas masing-masing sebesar $100 \%$ pada sistem outsourcing. Sejalan dengan penelitian Messina et al tahun 2012 yang meyatakan bahwa sebagaian besar respondennya menyatakan puas terhadap ketepatan waktu pemberian makan ${ }^{18}$. Berdasarkan penelitian, responden mengeluhkan ada keterlambatan waktu makan pada penyelenggaraan makanan sistem swakelola. Keterlambatan tersebut terjadi karena proses pemorsian yang membutuhkan waktu sehingga terjadi keterlambatan sekitar 15 menit. Waktu makan manusia secara alamiah dimana manusia akan terasa lapar yakni setelah 3 - 4 jam $^{6}$. Jika terjadi keterlambatan dalam pemberian makan maka dapat menurunkan selera pasien sehingga akan mempengaruhi kepuasan pasien. Ketepatan waktu pemberian makan dipengaruhi oleh proses distribusi makanan dan kecepatan petugas dalam menyiapkan makanan. Proses distribusi makanan erat kaitannya dengan jarak antara tempat penyelenggaraan makanan dengan tempat pasien sehingga apabil jarak antar keduanya cukup jauh maka membutuhkan waktu lebih dalam proses distribusi ${ }^{19}$.

Pada indikator kebersihan alat hidang, penilaian kepuasan makan pada penyelenggaraan makanan sistem outsourcing menunjukkan hasil yang lebih baik daripada sistem swakelola. Kebersihan yang dimaksud menurut peraturan Kemenkes tahun 2013 adalah tidak ada kotoran atau noda yang menempel di peralatan hidang pasien ${ }^{3}$. Kebersihan alat hidang merupakan hal terpenting dalam mencapai kepuasan makan konsumen. Seperti dalam penelitian Wulansari dkk (2013) menyatakan bahwa kebersihan alat makan memiliki rata-rata dari skor kepentingan sebesar 449 yang artinya bahwa kebersihan alat makan makan merupakan faktor yang sangat penting dalam penentu kepuasan makan ${ }^{14}$.

Pada aspek pelayanan petugas
pengantar makanan baik pada
penyelenggaraan makanan sistem outsourcing maupun swakelola, mayoritas responden menyatakan puas. Sikap petugas pengantar makanan yang menyenangkan dan suka membantu dapat menjadi elemen penting dalam peningkatan kepuasan makan pasien karena melalui pelayanan petugas terjalin komunikasi yang menghubungkan langsung dengan keadaan pasien mengenai penilaiannya terhadap pelayanan makanan ${ }^{5,20}$.

\section{Perbedaan Kepuasan Makan Pasien Antara Penyelenggaraan Makanan Sistem Outsourcing Dan Swakelola}

Penyelenggaraan makanan pasien di RS Islam Jemursari Surabaya yang pertama menggunakan sistem outsourcing selanjutnya berganti menjadi penyelenggaran sistem swakelola. Berdasarkan penelitian diketahui bahwa rata-rata tiap indikator penilaian kepuasan makan pada penyelenggaraan makanan sistem swakelola lebih tinggi daripada sistem outsourcing. Selanjutnya uji statistik menunjukkan bahwa pada indikator kualitas makanan (food quality) dan kepuasan makan total tidak ada perbedaan kepuasan makan pasien antara penyelengaraan makanan sistem outsourcing dan swakelola masing-masing dengan nilai $\mathrm{p}$ value sebesar 0,120 dan 0,123 . Namun ada pebedaan antara kedua sistem berdasarkan kualitas pelayanan 
makanan (foodservice quality) dengan $\mathrm{p}$ value sebesar 0,000 .

Penyelenggaraan makanan pasien dapat dilakukan dengan sistem outsourcing maupun swakelola yang masing-masing memiliki serangkaian kegiatan yang terstruktur mulai dari perencanaan menu, penerimaan bahan makanan, pengolahan, distribusi makanan ke pasien, hingga kegiatan pencatatan, dan pelaporan $^{3}$. Pemilihan sistem pada penyelenggaraan makanan khususnya pasien akan berpengaruh terhadap input, process, dan output dimana apabila input dan process kurang baik maka akan menghasilkan output (mutu makanan) yang kurang baik pula sehingga berpengaruh pada kepuasan pasien ${ }^{8}$. Berdasarkan hasil penelitian, rata-rata dari kualitas makanan (food quality) dan kualitas pelayanan makanan (food service quality) serta kepuasan total pada penyelenggaraan makanan sistem swakelola lebih tinggi daripada sistem outsourcing. Berdasarkan penelitian didapatkan hasil bahwa besar nilai rata-rata pada penyelenggaraan makanan sistem swakelola lebih besar daripada sistem outsourcing. Hal tersebut tidak sejalan dengan penelitian Yuliana (2007) yang menyatakan bahwa rata-rata kepuasan pasien dengan penyelenggaraan makanan sistem outsourcing lebih tinggi daripada sistem swakelola ${ }^{6}$. Kepuasan pasien merupakan cerminan output dari keberhasilan mutu pelayanan $^{21}$. Hal ini menunjukkan bahwa meskipun tergolong baru dalam mengadakan penyelenggaraan makan dengan sistem swakelola, pihak instalasi gizi RS Islam Jemursari telah dapat memberikan kepuasan makan yang tinggi terhadap pasiennya. Dengan penyelenggaraan makanan sistem swakelola, dapat memberi kesempatan untuk petugas gizi dalam melakukan pengawasan dan evaluasi secara langsung sehingga menu dapat diperbaki dari segi penampilan dan penyajian makanan ${ }^{6}$. Hasil analisis statistik menunjukkan bahwa tidak ada perbedaan bermakna pada kepuasan makan pasien berdasarkan kualitas makanan (food quality) antara penyelenggaraan sistem outsourcing dengan sistem swakelola di RS Islam Jemursari Surabaya. Namun ada perbedaan bermakna pada aspek kualitas pelayanan makanannya (foodservice quality). Hal tersebut berati bahwa dari segi kualitas makanan yang disajikan antara dua sistem tersebut hampir sama. Berbeda dengan kualitas pelayanan makanan yang memiliki perbedaan bermakna antar kedua sistem tersebut. Kualitas dan pelayanan makanan merupakan salah satu faktor yang paling penting dari penyelenggaraan makanan ${ }^{3}$. Kualitas pelayanan makanan meliputi ketepatan waktu pemberian makan, kebersihan alat hidang, serta pelayanan petugas pengantar makanan ${ }^{6}$.

Selanjutnya pada kepuasan makanan total, hasil analisa statisik menunjukkan bahwa tidak ada perbedaan bermakna pada kepuasan makan pasien total antara penyelenggaraan sistem outsourcing dengan sistem swakelola di RS Islam Jemursari Surabaya Hal tersebut tidak sejalan dengan penelitian Yuliana (2007) yang menyatakan bahwa ada perbedaan kepuasan makan pasien di RSU Dr. Zainoel Abidin dan RS Kesdam Banda Aceh. Penelitian yang sama juga dikutip oleh Yuliana (2007) yang menyatakan bahawa terdapat perbedaan kepuasan makan pasien antara RSUD Wonosari (menggunakan outsourcing) dan RSUD Panembahan (swakelola) ${ }^{6}$. Peralihan sistem penyelenggaraan makanan yang baru terjadi menimbulkan tidak ada perbedaan kepuasan makan antar keduanya. Kepuasan makan tidak hanya dipengaruhi oleh faktor eksternal tetapi juga faktor internal dalam diri individu pasien itu sendiri ${ }^{5}$. Kondisi pasien yang tidak normal menyebabkan terjadinya perubahan pengecapan, penciuman, dan perasa pada panca indera pasien sehingga berpengaruh pada penilaian kepuasan makan tanpa melihat sistem penyelenggaraan makanan yang sedang berlangsung ${ }^{16}$.

\section{KESIMPULAN}

Kepuasan makan pasien pada penyelenggaraan makanan sistem outsourcing tidak berbeda dengan kepuasan makan pasien pada penyelenggaraan makanan sistem swakelola. Bila dilihat dari hasil penelitian, diperoleh hasil bahwa nilai rata-rata kepuasan makan pada penyelenggaraan makanan sistem swakelola lebih tinggi daripada sistem 
outsourcing. Dalam mengoptimalkan kepuasan makan pasien, perlu diadakannya evaluasi mengenai kualitas makanan dan kualitas pelayanan makanan pada sistem swakelola yang sedang dijalani saat ini agar terjadi peningkatan dalam penilaian kepuasan makan pasien.

\section{ACKNOWLEDGEMENT}

Terima kasih dan penghargaan diberikan penulis kepada seluruh staf pengajar program studi ilmu gizi Universitas Airlangga atas bimbingan dan dukungan yang telah diberikan.

\section{REFERENSI}

1. Menteri Kesehatan. Peraturan Menteri Kesehatan RI Nomor 56 Tahun 2014 tentang Klasifikasi dan Perizinan Rumah Sakit. Undang-Undang. 2014. Available from http://manajemenrumahsakit.net. Diakses pada tanggal 12 Januari.2017.

2. Menteri Kesehatan. Menteri Kesehatan RI Nomor 129/Menkes/SK/II/2008 tentang Standar Pelayanan Minimal Rumah Sakit. Undang-Undang. 2008. Available from http://www.pelkesi.or.id. Diakses pada tanggal 12 Januari 2017.

3. Menteri Kesehatan. Pedoman Pelayanan Gizi Rumah Sakit. 2013. Available from http://gizi.depkes.go.id. Diakses pada tanggal 10 Januari 2017.

4. Semedi, P., Kartasurya, M., Hagnyonowati. Hubungan Kepuasan Pelayanan Makanan Rumah Sakit dan Asupan Makanan dengan Perubahan Status Gizi Pasien (Studi di RSUD Sunan Kalijaga Kabupaten Demak). Jurnal Gizi Indonesia 2013; 2(1) : hal 32-41. Available from

http://ejournal.undip.ac.id/index.php/jgi/ article/download/6343/5313. Diakses pada tanggal 02 Maret 2017.

5. Dall'Oglio, I., Nicolo, R., Ciommo, V, D., Bianchi, N., Ciliento, G., Gawronski, O., Pomponi, M., Roberti, M., Tiozzo, E., Raponi, M. A Sistematic Review of Hospital Foodservice Patient Satisfaction Studies. Journal of The Academyof
Nutrition and Dietetic 2015; 115(4) : 567584. Available from http://ac.elscdn.com. Diakses pada tanggal 16 Januari 2017.

6. Yuliana, D. Penilaian Mutu Makanan pada Sistem Penyelenggaraan Makanan yang Berbeda di RSU Dr. Zainoel Abidin dan di RS Kesdam Banda Aceh. Tesis. Universitas Gadjah Mada, 2007. p. 20-27.

7. Anonim. Profil Kesehatan RS Islam Jemursari 2016. Instalasi Gizi RSI Jemursari Surabaya. 2016

8. Pramono, A.,dan Widyastuti, N. Manajemen Jasa Boga. Yogyakarta : Graha Ilmu. 2014. P. 45 - 48.

9. Fallon, A, Gurr, S., Jones, M, H., Bauer, J, D. Use of The Acute Care Hospital Foodservice Patient Satisfaction Questionnaire to Monitor Trends in Patient Satisfaction With Foodservice at an Acute Care Private Hospital. Nutrition and Dietetics Journal. 2008; 65 (1) : page 41-46. Available from http://onlinelibrary.wiley.com/doi/10.11 $11 / \mathrm{j} .1747-$

0080.2007.00219.x/abstract;jsessionid $=0$ OD41AF5F2E01F4EEC3BBE7D104EB19F.f0 2t04. Diakses pada tanggal 20 Februari 2017.

10. Aliffianti, R. Tingkat Kepuasan Pasien Pada Pelayanan Makanan Di Rumah Sakit Aisyyah Purworejo. Skripsi. Universitas Negeri Yogyakarta, 2015. Hal. 15 -24. Available from http://eprints.uny.ac.id. Diakses Pada tanggal 16 Januari 2017.

11. Gobel, S, Y., Prawiningsih, Y., dan Budiningsih, R, Menu Pilihan Diit Nasi Yang Disajikan Berpengaruh Terhadap Tingkat Kepuasan Pasien VIP di Rumah Sakit Umum Provinsi Sulawesi Tenggara. Jurnal Gizi Klinik Indonesia 2011; 7(3) : hal 136 - 145. Available from https://jurnal.ugm.ac.id/jgki/article/view File/17755/11525. Diakses pada tanggal 30 Juli 2017.

12. Damayanti, S. Hubungan Variasi Menu, Besar Porsi, Sisa Makanan, dan Tingkat Kepuasan Pasien Pada Makanan Lunak di Rumah Sakit Umum Daerah Cengkareng. Skripsi. Universitas Esa Unggul Jakarta, 2014. p. 5-7. 
13. Kotler, P., Keller, K, Marketing Management (13th ed). New Jersey : Prentice Hall International, Inc. 2009. p. $32-33$.

14. Wulansari, A., Setiawan, B., Sinaga, T. Penyelenggaraan Makanan dan Tingkat Kepuasan Konsumen di Kantin Zea Mays Institut Pertanian Bogor. Jurnal Gizi dan Pangan 2013; 8 : Hal 151 - 158. Available from

http://jurnal.ipb.ac.id/index.php/jgizipan gan/article/download/7693/5959.

Diakses pada tanggal 28 Juli 2017.

15. Moehyi, S. Penyelenggaraan Makanan Institusi dan Jasa Boga. Jakarta: Bharata. 1992.

16. Nurqisthy, A., Adriani, M., Muniroh, L. Hubungan Kepuasan Pelayanan Makanan dan Tingkat Kecukupan Energi dan Protein dengan Status Gizi Pasien di RSUA Surabaya. Media Gizi Indonesia; 20161(1): hal 32 - 39.

17. Jessri, M., Mirmiran, P., Jessri, M., Johns, N., Rashidkhani, B., Amiri, P., Barfmal, N., Azizi, F. A Qualitative Difference. Patients'view of Hospital Food Service in Iran. Appetite Journal 2011; 57 : page 530-533. Available from http://www.sciencedirect.com/science/a rticle/pii/S0195666311005113 Diakses pada tanggal 20 Februari 2017.

18. Messina, G., Fenucci, R., Vencia, F., Niccolini, F., Quercioli, C., Nante, N.
Patients' Evaluation of Hospital Foodservice Quality in Italy : What Do Patient Really Vallue ?. Public Health Nutrition 2012; 16(4) : page 730-737. Available from https://www.cambridge.org/core/service s/aop-cambridgecore/content/view/4C686C7E8B5FA9711 B4A781CFA7F92B4/S1368980012003333 a.pdf/div-class-title-patients-evaluationof-hospital-foodservice-quality-in-italywhat-do-patients-really-value-div.pdf. Diakses pada tanggal 16 Januari 2017.

19. Kustiyoasih, M., Adriani, M, Nindya, T, S. Penyelenggaraan Makanan dan Kepuasan Konsumen di Lantai 2 Rumah Sakit Universitas Airlangga Surabaya. Media Gizi Indonesia, 2016; 11(1). Hal : $11-16$.

20. Johns, N., Hartwell, H., Morgan, M. Improving The Provision of Meals in Hospital. The Patients'Viewpoint. Appetite Journal, 2010; 54 : page 181 185. Available from http://ac.elscdn.com/S0195666309006424/1-s2.0s0195666309006424-

main.pdf?_tid=10ead4e8-3015-11e7-

$8 d 9 c-$

00000aacb35e\&acdnat $=1493825449$ 09b bc64453d98a93c0b70832d8be20d3

Diakses pada tanggal 03 April 2017

21. Imron, M. Manajemen Logistik Rumah Sakit. Jakarta : CV Agung Seto. 2009. hal. 10 